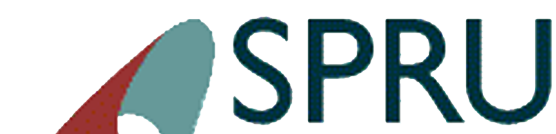

Science Policy Research Unit
Working Paper Series SWPS 2014-25

December, 2014

From Fuel Poverty to Energy Vulnerability:

The Importance of Services, Needs and Practices

\author{
Stefan Bouzarovski \\ Saska Petrova \\ Sergio Tirado-Herrero
}




\section{SPRU Working Paper Series}

The SPRU Working Paper Series aims to accelerate the public availability of the research undertaken by SPRU-associated people of all categories, and exceptionally, other research that is of considerable interest within SPRU. It presents research results that in whole or part are suitable for submission to a refereed journal, to a sponsor, to a major conference or to the editor of a book. Our intention is to provide access to early copies of SPRU research.

\section{Editors}

Tommaso Ciarli

Daniele Rotolo

\section{Associate Editors}

Florian Kern

Paul Nightingale

Matias Ramirez

Joe Tidd \&

Carlos Sato

Maria Savona \&

Mariana Mazzucato

Andrew Stirling Transitions

Caitriona McLeish Civil military interface

Area

Energy

Development

\section{Contact}

T.Ciarli@sussex.ac.uk

D.Rotolo@sussex.ac.uk
Science, \& Technology Policy

Technology Innovation Management

Economics of Technological Change

M.Savona@sussex.ac.uk

M.Mazzucato@sussex.ac.uk

A.C.Stirling@sussex.ac.uk

C.A.McLeish@sussex.ac.uk

\section{Disclaimer}

The works available here are the responsibility of the individual author(s) and do not necessarily represent the views of other SPRU researchers. As matters of policy and practice, SPRU does not endorse individual research contributions.

\section{Guidelines for authors}

Papers shall be submitted in pdf or Word format. They should contain a title, an abstract, and keywords. Papers should be submitted to one of the Editors, who will process them and send them to the appropriate Associate Editor. Two members of SPRU will be asked to provide a short written review within three weeks. The revised versions of the paper, together with a reply to the reviewers, should be sent to the Associate Editor, who will propose to the Editors its publication on the series. When submitting the authors should indicate if the paper has already undergone peerreviewing, in which case the Associate Editors may decide to skip internal review process.

\section{Website}

SWPS: www.sussex.ac.uk/spru/research/swps

IDEAS: ideas.repec.org/s/sru/ssewps.html 


\title{
From fuel poverty to energy vulnerability: The importance of services, needs and practices
}

\author{
Professor Stefan Bouzarovski ${ }^{1,2}$ (stefan.bouzarovski@manchester.ac.uk) \\ Dr Saska Petrova ${ }^{1}$ (saska.petrova@manchester.ac.uk) \\ Dr Sergio Tirado-Herrero' (sergio.tirado-herrero@manchester.ac.uk)
}

\author{
${ }^{1}$ School of Environment, Education and Development \\ University of Manchester \\ Arthur Lewis Building \\ Oxford Road \\ Manchester M13 9PL \\ United Kingdom \\ ${ }^{2}$ Visiting Professor \\ Department of Economic Geography \\ University of Gdańsk \\ Bazynskiego 4 \\ 80-952 Gdańsk \\ Poland
}

\begin{abstract}
This paper charts the emergent body of new approaches towards the research and amelioration of energy deprivation in the home. It starts from the premise that all forms of energy and fuel poverty - in developed and developing countries alike - are underpinned by a common condition: the inability to attain a socially- and materiallynecessitated level of domestic energy services. Emphasizing the functionings and capabilities provided by energy use in the residential domain has led us to question binary divisions between the fields of 'fuel poverty' and 'energy poverty' within, respectively, the global North and South. In order to move towards an integrated understanding of energy service poverty, we rely on 'systems of provision' paradigms to highlight the multiple socio-technical pathways that prevent the effective fulfilment of household energy needs. Based on such approaches, the paper identifies the main components and implications of 'energy vulnerability' frameworks, whereby the driving forces of domestic energy deprivation are seen through a dynamic heuristic predicated upon issues of resilience and risk. Using recent developments in Hungary as an example, we employ energy vulnerability thinking to illustrate the systemic driving forces and implications of domestic energy deprivation.
\end{abstract}

Keywords: energy services, energy vulnerability, energy poverty, fuel poverty, resilience, Hungary. 


\section{Introduction}

A recent special section of the journal Energy Policy devoted its attention to domestic energy deprivation across the UK and Europe. Titled 'fuel poverty comes of age' (Liddell, 2012), it charted the historical development of policy and scientific work on the issue of fuel poverty, largely founded upon Boardman's (1991) seminal contribution on the subject. From an 'occasional area of interest amongst a tiny group of demographers and survey statisticians' (Liddell, 2012 p. 2) that failed to garner mainstream political acknowledgment for a long time, fuel poverty has gradually become a widely recognized societal challenge among key academic, practitioner and policy-making circles.

Problems of energy deprivation in the home are also commonly described via the term 'energy poverty'. This concept has traditionally been used to capture problems of inadequate access to energy in developing countries, involving a host of economic, infrastructural, social equity, education and health concerns (Pachauri and Spreng, 2004). But a number of authors have been using energy poverty frameworks to encapsulate developed-world issues at the nexus of energy efficiency and affordability (Chester and Morris, 2011; Harrison and Popke, 2011; Katsoulakos, 2011; Petrova et al., 2013). With 'energy poverty' increasingly becoming a substitute for the term 'fuel poverty' in many European countries - and in contexts where the condition has not received scientific or policy attention to date, such as the US and the European Union - there is an increasing need for exploring the conceptual relationship between the two frameworks, and the governance implications of the emergent terminological diversity surrounding the lack of energy services in the home.

This paper investigates the possibility of cross-pollinating the fields of 'energy poverty' and 'fuel poverty' - as well as other ways of approaching domestic energy deprivation - into a genuinely global and integrated perspective on the driving forces and systemic impacts of inadequate domestic energy provision in its multiple guises and forms. Having reviewed the broader research settings in which these debates are currently taking place, the paper first focuses on the relational aspects of the problem: energy services and needs. This has allowed us to identify the commonalities that both undermine existing approaches and can help develop a more nuanced and inclusive framework. The subsequent section considers recent advances in research on systems of provision and social resilience in order to introduce a dynamic understanding of energy poverty via a vulnerability framework. We use this approach to explore the embeddedness of energy vulnerability in wider institutional and spatial configurations, using recent developments in Hungary as an example. The paper concludes by exploring the implications of such thinking for policy and science.

\section{Methods}

The research leading to this paper has combined analyses of primary and secondary evidence. Much of the findings presented here are the outcomes of reviews of existing literature in the domains of energy, poverty, human geography, environmental policy and social practices. The data from the literature review has been examined interpretively and via coding, resulting in three principal themes that are presented as separate sections in the text below. 
We have also sought to highlight the influence of fuel and energy poverty on both the material configuration of the energy sector, and the conduct of political debates and state policies at a variety of scales. Our evidence corresponding to this argument is articulated with respect to the situation in Hungary - a country in which over two decades of significant increases of household energy prices have unfolded against the presence of a fixed infrastructural setting in the form of an inherited energy-wasting residential stock, and an import-dependent domestic energy demand profile. The Hungarian case also allows for exploring the broader spatial implications of household energy strategies in response to broader processes of systemic change. Such processes are embedded in the on-going transformation of post-communist Central and Eastern European (CEE) nations, underway for 25 years (Bouzarovski et al., 2012a).

\section{Unpacking the dichotomy between fuel and energy poverty}

The recognition of 'fuel poverty' as a significant systemic problem is best established in academic and policy discourses within the UK and Ireland - states that have developed the longest tradition in researching and addressing problems of cold and energy-inefficient homes in particular, with their associated impacts for well-being and health (Baker et al., 2003; Boardman, 2010; Campbell, 1993; Fahmy et al., 2011; Healy and Clinch, 2004; Jansz and Guertler, 2012; Lawlor, 2001; Liddell, 2009; Liddell and Morris, 2010; Walker, 2008). Scholarship on the topic has recently expanded to include the post-socialist countries of Eastern and Central Europe (Buzar, 2007a, 2007b, 2007c; Fankhauser and Tepic, 2005; Kovačević, 2004; Petrova et al., 2013; Ruggeri Laderchi et al., 2013; Tirado Herrero and Ürge-Vorsatz, 2012a), as well as France (Derdevet, 2013; Devalière, 2013; Dubois, 2012), Germany (Billen, 2008; Heindl, 2013; Kopatz, 2009; Tews, 2014), Spain (Bilbao and Castro, 2013; Tirado Herrero et al., 2012; Tirado-Herrero et al., 2014), Austria (Brunner et al., 2012), Italy (Miniaci et al., 2008; Valbonesi et al., 2014), Greece (Dagoumas and Kitsios, 2014; Katsoulakos, 2011; Santamouris et al., 2007, 2013), Australia (Chester, 2013; Chester and Morris, 2011), New Zealand (Howden-Chapman et al., 2012) and even the US (Harrison and Popke, 2011). With policy measures aimed at combatting the problem being developed in many of these national settings, transnational bodies such as the European Union have become increasingly interested in formulating agendas that can provide wider and more comprehensive frameworks to address the problem (Bouzarovski et al., 2012b).

At the same time, a number of international development organizations and scholars have been focusing on the persistent deficiency of energy infrastructure provision across large parts of Africa, Asia, and South America. Despite a long history of international involvement and high profile political attention, more than 1.2 billion people across the world still lack access to electricity, while a further 2.8 billion have no choice other than traditional biomass for cooking and heating (World Bank, 2014). Termed 'energy poverty', this condition has received significant academic and policy attention (Gunningham, 2013; Pachauri and Spreng, 2004; Sagar, 2005), often as a result of its extensive impacts on well-being and health: every year, fumes and smoke from open cooking fires are estimated to contribute to the deaths of 1.5 million people, mostly women and children (World Bank, 2014). Developed-world energy poverty also has significant impacts on issues such as personal safety, household time 
budgets, labour productivity and income (Elias and Victor, 2005). It is a highly gendered problem, with women bearing the brunt of the consequences of inadequate energy access while suffering from systemic discrimination as well decreased access to resources and decision-making (Clancy et al., 2007; Pachauri and Rao, 2013).

Traditionally, energy poverty research in the developing world has mainly been focused on supply-side issues, emphasizing the need for extending electricity grids based on the experience of developed world countries (Lee et al., 1999; Munasinghe, 1990). Work undertaken by organizations such as the World Bank in particular has highlighted the benefits of extending the coverage of power grids into rural areas (Barnes, 2007; Cook, 2011; Foley, 1992; Pereira et al., 2010), as well as the economic, social and technical barriers to modern energy access (Watson et al., 2011) including the lack of adequate institutional infrastructures and financial capital (Bhattacharyya, 2006; Brew-Hammond, 2010; Green and Erskine, 1999; Haanyika, 2008; Ilskog et al., 2005; Steel, 2007). This has been demonstrated in case studies from Africa, South America and Southeast Asia alike.

In more recent years, scientific and policy attention has turned to the povertyamelioration potential of micro-generation and renewable energy investment as an alternative to top-down power grid expansion (Adkins et al., 2010; Bhide and Monroy, 2011). There has been an increased awareness of the cultural and political determinants of household energy transitions towards the use of modern fuels in developing countries (Campbell et al., 2003; Link et al., 2012; Murphy, 2001; Sehjpal et al., 2014). Also of relevance in this context is scholarship on the distributional and fiscal implications of state-led policies to address energy consumption (Dube, 2003; Karekezi and Kimani, 2002; Lin and Jiang, 2011), as well as the pathways through which increased access to modern fuels contributes to livelihood improvement and human development more generally (van Els et al., 2012; Kaygusuz, 2011; Ouedraogo, 2013; Zulu and Richardson, 2013). Debates on the 'other energy crisis' (Eckholm, 1975), therefore, have evolved from a supply-dominated logic underscoring the under-development of technical infrastructures to a more nuanced understanding of the multilayered political economies and relations of power that underpin the emergence and persistence of energy poverty (Sovacool, 2012).

As was pointed out above, global issues of energy equity have been historically considered within two relatively separate scientific and policy registers (although 'fuel poverty' has also been used in developing-world settings, see Bruce, 2001; Terry, 2009; Bhattacharyya, 2011). While discussions and measures surrounding 'fuel poverty' have been largely seen within the context of unaffordable warmth in the home - and as such have mainly fallen under the remit of economists, sociologists, environmental scientists and engineers - perspectives on energy poverty in the global South have been closely articulated in relation to the interdisciplinary field of development studies, in addition to focusing on issues of access, equity and investment in socio-technical systems. But the increasing globalization and marketization of energy flows, accompanied by the proliferation of research on developed world energy deprivation - in contexts where this condition previously received little public recognition - has started to disturb this division. 'Energy poverty' is no longer confined to developing world debates, while the accessaffordability binary is gradually being dismantled and challenged. Policy and scholarship in many European countries - and even the European Union itself - uses 
the term 'energy poverty' to encompass questions of access, infrastructure, health and equity in addition to the more established issues of affordability and efficiency (Bouzarovski, 2013; Braubach and Ferrand, 2013; Hall et al., 2013; Hiteva, 2013; Walker and Day, 2012). And questions of security, justice, and socio-technical transition are jointly entering the vocabularies of energy and fuel poverty researchers across the world (Fouquet, 2010; Goldthau and Sovacool, 2012; Kaygusuz, 2011; Pachauri and Jiang, 2008).

The destabilization of the traditional conceptual boundaries of fuel and energy poverty has created the need for exploring the relationship between these frameworks and the wider socio-spatial mechanisms that underpin the lack of adequate energy services in the home. As a result, some strands of work on the topic have begun to challenge the theoretical assumptions that underpin both paradigms. Yet other than statements that the two terms have the same meaning in developed-world contexts (Boardman, 2010; Bouzarovski et al., 2012b) an explicit conceptual discussion of the relationship between energy and fuel poverty has been lacking for a long time. (Li et al., 2014) are among the limited number of authors who have ventured into this territory, by arguing that fuel and energy poverty are distinct problems that can be associated with accurate descriptors: access to electricity, education, health, and the International Energy Agency's Energy Development Index (EDI) or Nussbaumer et al.'s (2012) Multidimensional Energy Poverty Index (MEPI) in the case of energy poverty; and affordability, thermal comfort and Hills' (2012) Low Income High Cost (LIHC) measure in the case of fuel poverty. They elaborate such claims by insisting that 'fuel poverty mostly occurs in relatively wealthy countries with cold climates' $p$. 480 (such as residents of the UK, Ireland and New Zealand), whereas 'energy poverty occurs across all climates but mostly in poor countries' (mainly Central South America sub-Saharan Africa and central Asia). The only people who may experience both fuel and energy poverty at the same time are those 'living in a cold climate, and they have difficulty in getting access to electricity or modern cooking facilities, and with indoor heating at an appropriate cost' ( $p$ 480); they include 'areas of northern rural China, Nepal, India and scattered instances of homeless people in developed countries'.

A closer scrutiny of Li et al.'s (2014) bracketing of the conceptual remit of energy poverty and fuel poverty reveals several fundamental problems. In particular: how would their approach work in the case of households who experience domestic energy deprivation, while living in relatively affluent countries with warm climates? For example, a wide range of authors - from Healy (Healy, 2004) to Tirado-Herrero et al. (Tirado-Herrero et al., 2014) - have found that relatively affluent countries in Southern Europe, such as Portugal, Greece, Spain, Cyprus, Malta and Italy, contain record numbers of households who lack adequate energy provision in the home. This concerns both suboptimal levels of space heating in winter and residential cooling in summer, and can be attributed to a combination of infrastructural, income and cultural factors. And what to make of middle-income states in regions like Central Asia or South America, where governments face parallel problems of energy access and affordability in, respectively, predominantly rural and urban areas? Clearly, the rigid domains of scientific and policy thinking identified by (Li et al., 2014) become untenable when faced with the diversity of conditions and practices surrounding issues of energy equity across the world. 
Counter to efforts to curtail the emergent terminological messiness developing around the notions of fuel and energy poverty, we argue that this situation provides a starting point for advancing scientific and policy debates on the fundamental relationships among energy access, affordability and state policy. Our claim is based upon the premise that that all forms of household-scale energy deprivation share the same consequence: A lack of adequate energy services in the home, with its associated discomfort and difficulty. When cross-referenced with the most widely acceptable definition of relative income poverty (a condition with a global definition - see (Foster, 1998) both fuel and energy poverty can be considered under the same conceptual umbrella: as a set of domestic energy circumstances that do not allow for participating in the lifestyles, customs and activities that define membership of society (Buzar, 2007a).

\section{Energy services and needs: universal phenomena}

If there is one common thread that connects both developed and developing world countries with respect to the underconsumption of energy in the home, it is the pivotal role of 'energy services'. Commonly understood as the 'benefits that energy carriers produce for human well being' (Modi et al., 2005 p. 9), energy services allow for shifting the perspective away from 'fuels' such as 'coal, oil, natural gas, and uranium, and even ... sunlight and wind, along with complex technologies such as hydrogen fuel cells, carbon capture and storage, advanced nuclear reactors, and superconducting transmission lines, to name a few' (Sovacool, 2011a) onto the notion that 'people do not demand energy per se but energy services like mobility, washing, heating, cooking, cooling and lighting' (Haas et al., 2008 p. 4013). As a result, policy challenges can start to revolve around issues such as achieving 'adequate levels of light rather than delivering kWh of electricity' (Sovacool, 2011a p. 1659).

Energy service approaches also highlight the inadequacy of existing measurement frameworks for understanding and monitoring energy delivery in the home, which is mainly captured by the number of energy units consumed by the carrier, or the effect that the conversion process has on affected spaces (such as levels of temperature or illumination). Neither of these metrics properly describe the utility and satisfaction received by the final user, partly because the effect of the energy service on his or her requirements - principally a comfortable and well-functioning home - is largely dependent on subjective variables (Crosbie and Guy, 2008; Karjalainen, 2007; Petrova et al., 2013; Rudge, 2012). It thus becomes important to consider the individual, household and community-level determinants of energy dynamics in the residential environment, by taking into account the role of wider environmental, cultural, technical and architectural factors in influencing energy comfort (Aune, 2007; Lutzenhiser, 1992; Stephenson et al., 2010).

Thinking about energy in terms of the domestic functions that it affords also allows for considering the wider technologies and dynamics involved in the operation of modern homes. The relatively simple (and somewhat out of date) classification of energy services provided by authors such as Reister and Devine (1981) and further enshrined in the 'energy ladder' and 'fuel stacking' models (Masera et al., 2000; Nansaior et al., 2011; Peng et al., 2010; Sovacool, 2011a, 2011a) - space heating, water heating, space cooling, refrigeration, cooking, drying, lighting, electronic services, and appliance services - quickly starts to break down when the relevance of 
other processes in the home is considered within this context. The inherently multifunctional nature of energy services means that carriers with one primary purpose often serve a range of secondary roles, many of which are not explicitly linked to energy. Thus, a wood-burning stove can provide space heating, hot water, cooking, drying and light, as well as a feeling of coziness, comfort and a focal point in the home (Cupples et al., 2007; Petersen, 2008; Reeve et al., 2013). At the same time, a single energy service can be supplied by a range of different fuels: 'Illumination, for example, can come from candles, kerosene lamps, or electricity' (Sovacool, 2011b p. 218).

Further testifying to the multifaceted nature of energy services is their complex composition, which entails 'different inputs of energy, technology, human and physical capital, and environment (including natural resources)' (Haas et al., 2008 p. 4013). This means that energy services cannot be understood in solely technological or social terms, but rather represent hybrid 'assemblages' (Bennett, 2005; McFarlane, 2011) operating across a multitude of scales and sites, beyond the confines of the home. As such, they consist of 'composite accomplishments generating and sustaining certain conditions and experiences' (Shove, 2003 p. 165) that are deeply embedded in the 'orchestration of devices, systems, expectations and conventions' (ibid). Hence, energy services embody social practices that are 'configured by the "hanging together" of institutional arrangements, shared cultural meanings and norms, knowledges and skills and varied material technologies and infrastructures' (Walker, 2014 p. 49). The routines that coalesce around systems of provision can thus be studied via a social practice approach that requires 'stepping back from energy itself' (ibid) and moving beyond issues of technological or behavioural efficiency in the series of transformations that lead to the production of useful energy - however important these may be - onto the manner in which end-use energy demand is articulated in time and space (Bridge et al., 2013; Castán Broto et al., 2012; Jalas and Rinkinen, 2013; Ozaki and Shaw, 2014; Walker, 2014).

At a more fundamental level, energy services are driven by needs, which reflect what the recipients of this system of provision effectively require: 'A cooked meal, a well lit room, a fast computer with an internet connection, a cold beer, a warm bed, mechanical power for pumping or grinding' (Sovacool, 2011b p. 218). As such, the fulfillment of energy needs is a crucial component of the functionings that enable individuals to perform their everyday life and achieve well-being (Nussbaum, 2011; Saith, 2001; Sen, 2009). But needs are themselves closely conditioned by the social practices that inform the social expectations and settings in which energy use takes place. This is particularly obvious in the case of electricity, whose technical versatility and flexibility (Smil, 2003) has often prompted actors on the supply side to actively manage and produce energy demand. Despite its intractability and vastness, therefore, the entire electricity system can be seen 'as an element of electricity-consuming social practices, informing what makes sense for householders to do during (and outside) peak periods' (Strengers, 2012 p. 230).

Given the pivotal role of energy services in understanding the underlying dynamics that lead to poverty, it is remarkable how little systemic attention they have received outside the familiar tropes of engineering or economic evaluation. The academic literature on the subject displays a limited understanding of the levels of domestic energy service that consumers regard as sufficient for the normal conduct of everyday 
life in different geographical and cultural settings. Nevertheless, the suggestion that energy consumers throughout the world require service standards that would allow them to have 'effective opportunities to undertake the actions and activities that they want to engage in, and be whom they want to be' (Robeyns, 2005 p. 95) provides a starting point for moving beyond some of the conceptual quandaries at the accessaffordability nexus, as described above. In the first instance, this suggests that thinking about fuel or energy poverty in terms of 'basic needs' (Brunner et al., 2012; Makdissi and Wodon, 2006; Pachauri et al., 2004; Roberts, 2008a) does not adequately capture the full array of household requirements and functionings. Moreover, the fact that energy services are themselves the outcomes of a complex set of conversions and networks implies that the driving forces of domestic energy deprivation are multidimensional and hybrid, while extending beyond the developeddeveloping country distinctions that some authors have attempted to make.

At this point, it should be emphasized that the literature on developing world energy poverty generally displays a more sophisticated understanding of the relationship between energy services and household needs (see, for example, Sovacool, 2011a). While much of this work lacks an explicit theorization of the everyday grain of energy needs and services, it does offer an invigorated perspective on the importance of human security, democratic participation and social cohesion for the development of energy systems as they relate to individual household requirements. For example, van Els et al. (2012) highlight that market mechanisms have not been sufficient to guarantee the economic sustainability of rural electrification projects in the Amazon, underlining the need for a paradigm shift towards local mobilization and organization via development initiatives so as to partnership between local new actors in the electricity sector and governmental bodies. At the same time, arguments about the importance of 'just grids' and 'good governance' (Bazilian et al., 2010) have been accompanied by an increased awareness of the importance of political, institutional and cultural factors in influencing energy poverty (Watson et al., 2011) beyond more conventional economic, financial and technical considerations. Energy service approaches have also underlined the importance of moving beyond electrification onto the provision of heating and cooking services in the home (Bazilian et al., 2012), as well as the need for considering broader issues of geopolitical risk and uncertainty in the governance of systems of provision (Bradshaw, 2010; Jansen and Seebregts, 2010).

Such concerns have also started to permeate the work of policy-making organizations at different scales. In response to the omission of energy in the UN millennium development goals, work undertaken by the UN Development Programme report proposed practical steps towards 'scaled-up investments in health, education, and infrastructure, alongside efforts to promote gender equality and environmental sustainability' (Modi et al., 2005 p. i). In 2012, the Sustainable Energy for All initiative gave prominence to the impact of international and local policies on the provision of energy services at the local scale, while foregrounding the need for integrated thinking to address concerns of climate change, natural resource scarcity, and global income inequality (Mahama, 2012). Also of note is the UK Department For International Development's statement that 'energy in a development context is not about technology provision first ... but about understanding the role that energy services play within people's lives' (Department for International Development (DFID), 2002 p. 21) calling for a 'people- centred approach, reaching beyond the 
technical issues, to deliver energy services that meet peoples' needs and priorities' (ibid: 24).

\section{Systems of provision: Energy vulnerability pathways as drivers of deprivation}

A shift of perspective away from fuels and onto services in conceptualizations of fuel and energy poverty opens the path for considering the role of role of 'systems and infrastructures of provision' (Fine and Leopold, 1993; Seyfang and Haxeltine, 2012; Southerton et al., 2004; Wilhite et al., 2000) in contributing to the rise of domestic energy deprivation. Systems of provision, put briefly, describe, inter alia, the institutional dynamics and material cultures surrounding the rise of commodityspecific chains that connect production, distribution and consumption activities. By assigning a 'vertical' logic (Fine, 1993) to the circulation of commodities and services, systems of provision approaches affirm the multiple interdependencies and standardizations that allow for the delivery of specific goods and services to the final consumer. But they also highlight the role of horizontal factors on the different components of the provision chain; in the case of energy, these can include the nature of the built environment of the home, as well as the articulation of social practices and energy needs.

In the mainstream literature on developed world 'fuel poverty', the dynamics that underpin the condition are mainly identified within the narrow triad of low household incomes, high energy prices, and inadequate levels of energy efficiency. But bringing needs into the equation leads to the conclusion that individuals who spend a greater degree of the day at home (such as pensioners or unemployed people) or have special energy requirements (including disability or the presence of small children) are more likely to suffer from domestic energy deprivation than the rest of the population, as their socio-demographic circumstances mean that such households demand aboveaverage amounts of end-use energy (Buzar, 2007c; Roberts, 2008b; Wrapson and Devine-Wright, 2014; Yohanis, 2012). This situation can transpire irrespective of the affordability of energy prices, or the lack of residential energy efficiency. Energy or fuel poverty may also arise as a result of a mismatch between the heating or cooling system installed in the dwelling, on the one hand, and the energy service needed by the occupant household, on the other. For example, electric night storage heating is not the most economic option for households who only use the home in the evenings (Milne and Boardman, 2000; Osbaldeston, 1984; Rudge, 2012); and district heating systems that do not have individual controls or thermostats may provide unaffordable for residents who end up 'trapped in the heat' at undesirable times of the day (Tirado Herrero and Ürge-Vorsatz, 2012a). In situations where the structural fabric of the building, housing tenure and other legal obstacles do not allow for switching to a more suitable heating system, the household affected by the situation may find itself suffering from inadequate energy services even if it is otherwise able to afford the energy that it consumes, while living in a home that is well insulated (Buzar, 2005, 2007a).

Conceptualizing energy deprivation in terms of services, needs and practices can also destabilize dominant understandings of the driving forces of this condition in developing countries. A recognition of the need for energy as a socially necessitated phenomenon above basic biological requirements problematizes the idea that minimum standards can provide for adequate individual functionings. Given the 
multiple socio-technical trajectories through which any given service can be procured, this suggests that the reduction of energy poverty measurement and indicator frameworks to particular carriers (in contributions such as, for instance, Pachauri, 2011) cannot capture the entirety of household needs and situations across the world. Of particular importance here are claims that the households primarily desire an energy supply that is reliable, affordable and accessible (Sovacool, 2011a) whereby 'the use and security of energy services is not ingrained but rather conditioned strongly by income and relative wealth within societies' (page 1667). The linear logic of energy ladder and stacking models is also destabilized by the multiple functions enabled by energy services - from domestic comfort to personal identity. For example, the use of traditional biomass is predicated upon 'active decision making on the part of individual households according to their preferences and broader lifestyle considerations' (Hiemstra-van der Horst and Hovorka, 2008 p. 3342) in developing and developed countries alike.

The manner in which state bodies and utilities choose to price energy or support particular groups also plays a powerful role in determining whether a household is likely to live in conditions of domestic energy deprivation. This is where injustices of distribution, procedure and recognition (Walker and Day, 2012) become important factors in driving fuel or energy poverty before even considering issues of income, price or efficiency. Indirect subsidies embedded in the energy tariffs, for example, have a very significant impact in determining patterns of deprivation (Freund and Wallich, 1996; Ruggeri Laderchi et al., 2013). Also significant in this case are fiscal or pricing measures targeting particular types of fuel; while taxes on diesel and petrol - and even natural gas - are generally less harmful to the poor, it has been demonstrated that placing the tax burden onto electric bills often highly disproportionately affects poor households (see, for example, (Poltimäe and Võrk, 2009). In addition, it should be pointed out that 'schemes that put a price on carbon emissions further upstream ... have an effect not only on downstream energy prices but also on all other goods and services owing to the higher price of the energy used in their production' (Büchs et al., 2011 p. 291). In some cases, fuel or energy poverty assistance schemes can exacerbate the very condition that they are meant to target by privileging particular groups over others. Regulatory obstacles, information scarcity and socio-cultural factors often prevent socially excluded groups from accessing support (Boardman, 2010).

All of this points to the need for recasting both fuel and energy poverty in terms of the broader notion of 'energy service poverty'. Such an approach would allow for the entire range of factors contributing to domestic energy deprivation to be integrated into a single conceptual framework (see Figure 1), focusing on the horizontal elements that influence the vertical system of provision as highlighted above. At the core of such thinking is that the fulfilment of household energy demand takes place via a complex socio-technical pathway that involves the delivery of fuels to the home via an 'energy chain' (Chapman, 1989), and the conversion of end-use energy into final energy services. A household's energy needs, which are at the final point of this system while driving its emergence, may not be met if established social practices (via dynamics of distribution, procedure and recognition) or residential inflexibilities (tenure and fuel switching difficulties in particular) prevent it from enjoying the full benefits of the energy service required. Energy poverty may also arise in instances where the conversion efficiency that leads to the final energy service is low, or the 
type of fuel that the household desires is physically or economically inaccessible due to a lack of infrastructure or affordability.

Figure 1: Dimensions influencing the delivery of energy services to the home, and the rise of domestic energy deprivation.

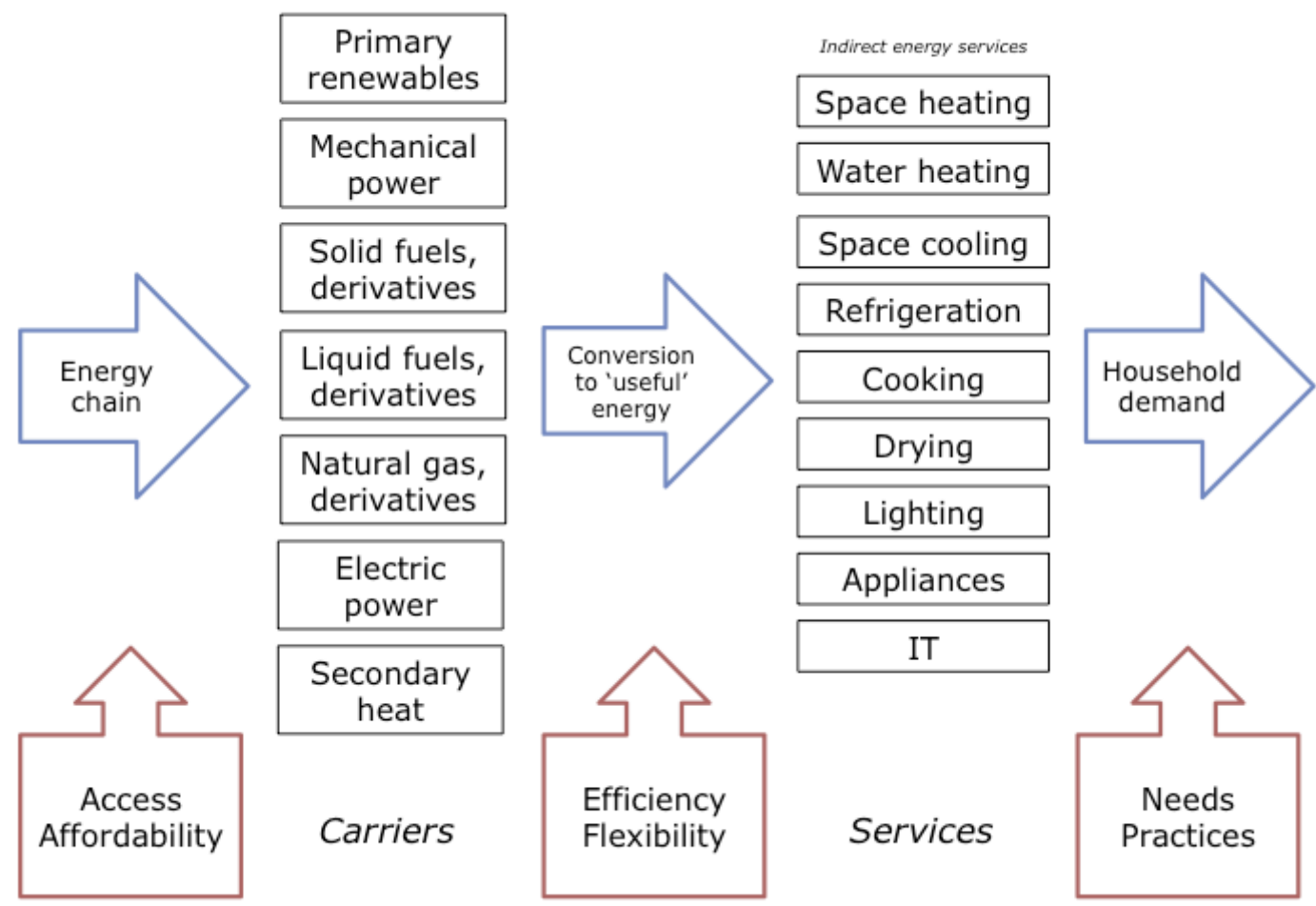

In this context, it is important to note that energy and fuel poverty - or 'energy services poverty' for that matter - are themselves only descriptors of a state or moment in time, and cannot capture the dynamic interrelationships among the factors outlined in Figure 1. A number of authors have called attention to the temporal variability of domestic energy deprivation: it is known that external or internal factors may push particular social groups into poverty at given points, and some households can exit the condition if their circumstances improve.

The factors that contribute to the rise of domestic energy deprivation can be captured under the concept of 'energy vulnerability' - defined, simply, as the propensity of an individual to become incapable of securing a materially and socially needed level of energy service in the home. Energy vulnerability thinking brings to the fore issues of resilience (Bouzarovski et al., 2010; O'Brien and Hope, 2010; Welsh, 2014) and precariousness (Paugam, 1995), by highlighting how relevant driving forces can belong to circumstances that are either internal or external to the household (Table 1). It emphasizes the fact that external spheres of action tend to be located at the far ends of the provision system - with most energy vulnerability issues being internal to the household. Such thinking is not only useful in identifying groups that may be at risk of falling into energy poverty in the future, but can also help place the combination of social, economic, political and infrastructural factors that have contributed to the 
position of households who are facing the predicament in the present. This is particularly true in the case of developed-world urban households living in transitory housing arrangements - mainly young people, tenants in private rental housing, and residents of informal settlements - which are difficult to detect and target using conventional policy frameworks (Bouzarovski et al., 2013; Jencks and Peterson, 2001; Visagie, 2008). In developing country contexts, the framework highlights the crucial importance of ensuring that the technical and financial availability of energy carriers is matched with socially-necessitated household needs.

Table 1: A typology of energy vulnerability factors and their constituent elements

\begin{tabular}{|l|l|l|}
\hline Factor & Components & Stressors \\
\hline Access & $\begin{array}{l}\text { Poor availability of energy carriers appropriate to } \\
\text { meet household needs }\end{array}$ & External \\
\hline Affordability & $\begin{array}{l}\text { High ratio between cost of fuels and household } \\
\text { incomes, including role of tax systems or } \\
\text { assistance schemes. Inability to invest in the } \\
\text { construction of new energy infrastructures. }\end{array}$ & External/internal \\
\hline Flexibility & $\begin{array}{l}\text { Inability to move to a form of energy service } \\
\text { provision that is appropriate to household needs }\end{array}$ & Internal \\
\hline $\begin{array}{l}\text { Energy } \\
\text { efficiency }\end{array}$ & $\begin{array}{l}\text { Disproportionately high loss of useful energy } \\
\text { during energy conversions in the home }\end{array}$ & Internal \\
\hline Needs & $\begin{array}{l}\text { Mismatch between household energy requirements } \\
\text { and available energy services; for social, cultural, } \\
\text { economic or health reasons }\end{array}$ & Internal \\
\hline Practices & $\begin{array}{l}\text { Lack of knowledge about support programmes or } \\
\text { ways of using energy efficiently in the home. }\end{array}$ & Internal/external \\
\hline
\end{tabular}

\section{Energy vulnerability as a systemic issue: the Hungarian case}

Post-communist countries offer a rich testing ground for untangling the complex relationships among energy system restructuring, spatial formations and deprivation. These states have been subject to extensive economic and political reforms during the past two decades, as a result of the stated objective of moving towards a market-based economy. In the energy sector, the reform process has entailed efforts to unbundle and privatize state owned utility companies, and increase energy prices (Buzar, 2007d; Fankhauser and Tepic, 2007). The character and sequencing of such measures have been shaped, in part, by the socio-technical legacies of communist central planning: a supply mix dominated by imported hydrocarbons and polluting lignite, a thermally inefficient and ageing housing stock, widespread district heating networks, and compact urban structures (Ürge-Vorsatz et al., 2006). At the same time, significant differences in access to modern energy services between urban and rural areas have combined with the emergence of informal economic practices to create a divergence between monetary deprivation and material poverty. The incompatibility of distributional or procedural justice frameworks with the driving forces and patterns of energy poverty has been further amplified by the significant role of infrastructural and institutional path-dependencies in influencing the emergence of post-communist social inequality. 
Hungary is a typical post-socialist country with respect to the nexus between energy, social welfare and housing. It has been estimated that a substantial fraction (between 10 to 30 per cent) of the Hungarian population was living in energy poverty as of the end of the past decade, with the share of households experiencing disproportionately high 'energy burdens' - defined as the share of energy costs in family incomes steadily increasing since the mid-2000s (Tirado Herrero, 2013). Energy poverty is largely a post-communist phenomenon in this country, and as such is embedded in the wider regional transformations described above. As elsewhere in CEE, systemic pathdependencies from the period of communist central planning have played a key role in the recent emergence of energy poverty in Hungary.

Structural legacies inherited from the past are and foremost evidenced by the poor thermal performance of the country's residential buildings, many of which were built during communism. A particularly relevant example is the stock of single-family houses built prior to the 1990s, whose ubiquitous presence in rural and suburban areas makes them the most common residential building type in Hungary. They take up more than 50 per cent of the country's total residential floor area (Tirado Herrero, 2013). Because of their building characteristics (such as poor surface-to-volume ratio) and the fact that many were built informally by families who tried to circumvent the lack of a functioning housing market by working manually with relatives, friends and acquaintances (Hegedüs et al., 1994), they are also the most energy inefficient building type - the specific energy demand for space heating suspected to be in the range of 300 to $500 \mathrm{kWh} \mathrm{m}^{-2}$ year $^{-1}$ (Tirado Herrero, 2013). Other building forms (e.g., multi-family buildings of various ages) are supposed to have a lower specific energy demand - from 120 to $230 \mathrm{kWh} \mathrm{m}^{-2}$ year $^{-1}$ (Tirado Herrero, 2013) - which is still far from optimal.

Another significant example of inefficiencies in the residential energy supply system is provided by the existence of pre-fabricated multi-apartment panel blocks in large housing estates - the flagship of communist housing policies. Often supplied with district heating networks, they currently host an unconventional typology of energy poverty as a result of high domestic energy costs, the lack of individual consumption meters and the inability to switch fuels (Tirado Herrero and Ürge-Vorsatz, 2012b). The poor efficiency of Hungary's buildings has consequences beyond domestic energy affordability issues, given that the residential sector is responsible for a large percentage of the country's final energy consumption, and therefore of its greenhouse gas emissions. Even though Hungary has easily achieved its Kyoto protocol mitigation target and its current (as of 2012) emissions are 20 per cent below 2000 levels, achieving the 2050 European Union reduction target of 80 to 95 per cent would require a significant overhaul of the country's infrastructure, including its residential stock (EC, 2011).

Hungary's substantial import natural gas dependency has been adding to this situation. The country's overall heavy reliance on gas can be traced back to the discovery of large domestic gas reserves during the 1960 and 1970s (Kessides, 2000). However, it is also the result of decisions taken in more recent years, such as extensive replacement of tile stoves and coal and oil boilers with more efficient gas boilers between 1990 and 1998 - a process further enhanced the regulation and subsidization of domestic energy prices (Energia Központ, 2008). 
This emergent landscape of energy vulnerability is being confronted by households via a wide range of 'coping strategies' (Brunner et al., 2012) whose pervasiveness is beginning to effect structural changes in overall patterns of fuel consumption in the country, while challenging the notion that deprived groups are passive subjects with a limited capacity to adapt to new circumstances. Household responses to energy poverty are evidenced by size of the population experiencing 'arrears in utility bills', whose number changed from 15 to 25 per cent between 2005 and 2013 - a trend consistent with the rise in energy price and expenditures described above. In addition to the expansion of energy poverty, this development demonstrates the agency of vulnerable populations: households may purposely choose to delay the payment of expensive energy bills in order not to run out of money in the winter months, thus transferring the financial consequences of energy poverty to the utility providers. From the households' perspective, the flip side of this coping strategy is the risk of falling into indebtedness, resulting in disconnection or the installment of pre-payment meters (Szivós et al., 2011). However, the same socio-technical configurations that force households into energy deprivation also protect indebted energy users. Such is the case of pre-fabricated panel buildings supplied by district heating without individual consumption meters and one-pipe, single-loop vertical hot water distribution systems, where the disconnection of individual households is technically impossible (OECD/IEA, 2004). Arrears and non-payment reinforce the energy vulnerability loop as they undermine the capacity of district heating providers to invest in the maintenance or upgrading of the system (Poputoaia and Bouzarovski, 2010).

The wider socio-spatial implications of energy poverty are also effectuated via the substitution of modern energy carriers - mostly natural gas - by traditional or solid fuels for domestic energy heating. This process, sometimes termed 'energy degradation' (Bouzarovski et al., 2012a), has been reported in several ECE states (Fankhauser and Tepic, 2007; UNDP, 2004). It is evidenced by the fact that approximately 36 per cent of Hungarian households were relying on solid fuels in 2011, as opposed to 14 in 2005. The trend transpired despite the presence of piped gas links in 76 per cent of dwellings and 96 per cent of settlements in Hungary (KSH, 2014), even if the amount of natural gas consumed per household dropped from 1,457 $\mathrm{m}^{3}$ per year in 2005 to $934 \mathrm{~m}^{3}$ per year in 2011 (KSH, 2014). The reliance on solid fuels has displayed a powerful income differential, with over half of all households in the bottom decile resorting to this source of energy (Table 1). The propensity for lower-income households to consume solid fuels are indicative of the increasing inequality in the purchasing power of households, rather than matters of evolving cultural or economic preferences.

Table 1. Percentage of Hungarian households who dedicated more than 10 per cent of their energy expenditure to solid fuels in 2005 and 2011. Source: KSH.

\begin{tabular}{|l|l|l|l|l|l|l|l|l|l|l|}
\hline Decile & 1 & 2 & 3 & 4 & 5 & 6 & 7 & 8 & 9 & 10 \\
\hline 2005 & 57 & 39 & 33 & 31 & 25 & 25 & 24 & 17 & 12 & 5 \\
\hline 2011 & 60 & 48 & 48 & 44 & 43 & 39 & 33 & 31 & 21 & 13 \\
\hline
\end{tabular}

As a result of these developments, firewood - the dominant solid fuel consumed by Hungarian households, alongside coal and woodchips - now trails natural gas as the second most common energy carrier for domestic space heating, even though both 
fuels are often used synchronously (Energia Klub, 2011). Households who predominantly rely on firewood also report heating a smaller fraction of their dwelling space (Energia Klub, 2011), which emphasizes the unequal character of this practice. Switching to firewood as a strategy to reduce domestic energy expenditures has been a spatially uneven phenomenon as there is evidence to suggest that its prevalence has been influenced by the location and socio-technical characteristics of relevant households and dwellings. Firewood is more common in rural areas, where it is more easily accessible through self-collection or purchase. Single family home are associated with the highest rate of firewood consumption (33 per cent of households, in addition to a further 15 per cent using both firewood and natural gas), possibly because such dwelling types are more likely to be equipped with storage space, stoves and chimneys. Firewood use is less common in multi-family apartment blocks ( 3 per cent of households, with an additional 6 per cent using both natural gas firewood and natural gas) and practically non-existent in pre-fabricated panel buildings dating from the 1960s to 1980s (Energia Klub, 2011). Consequently, this coping strategy is thought to be absent from city centres and housing estates built during socialism. Location interacts with other variable such as household age and composition, with older people being disadvantaged in spite of their greater needs for affordable warmth (Tirado Herrero, 2013).

Successive Hungarian governments have been making various attempts to buffer the impact of growing energy prices on the purchasing power of Hungarian households and voters. These politically motivated policy interventions, which are still ongoing, have mainly taken the form of regulated energy prices and relatively short-lived subsidy schemes. They evidence the pervasiveness of energy vulnerability in Hungary, which has forced actors on the national political scene to take an explicit stand towards the issue in order to secure enough electoral support.

Price regulation has a historical legacy in Hungary, as a result of the practices inherited from communism and the fact that all residential gas consumers benefitted from implicit tariff subsidies until the mid-2000s. According to the World Bank, in those years domestic consumers were favoured by a low residential-to-industrial price ratio and by the government's ability - through the Hungarian Energy Office - to buffer the impact of high import tariffs on domestic consumers by regulating the increases in retail gas prices. The latter practice was put in place in the late 1990s by the government of in response to the emergence of gas price increases as a major issue in the 1998 elections, following a decade of significant tariff reform (Kessides, 2000; OECD/IEA, 2007). While this intervention managed to keep prices under control, it led to the accumulation of losses in the balance sheets of distribution companies until 2006, when the regulated retail price of natural gas fell below the import price and the accumulated losses of the wholesaler (E.On Földgaz Trade) peaked at 112 billion HUF. A major increase in regulated prices was thus decreed in the same year, in line with the broader liberalization of the gas sector. As a result, the accumulated losses of the regulated wholesaler were reduced to the tune of almost 20 billion HUF in early 2008 (E. On. Földgaz, 2008), while triggering the 'price hike' described above. In 2009, a new Gas Act eliminated the obligation to compensate the losses incurred, by citing the difference between import prices and retail prices (ibid.).

In addition to regulated prices, households have benefitted from natural gas and district heating (DH) price support schemes (gázártámogatás and távhötámogatás) 
since the early 2000s. Originally, these programmes offered general support to residential gas and DH customers - subsidies was paid to all households connected to the two networks, without any consideration of financial or occupancy status (OECD/IEA, 2007). In order to provide more direct targeting, the government introduced eligibility criteria in 2007, based on energy consumption, household size and monthly income. Yet more than half of Hungary's domestic gas and DH consumers still qualified as recipients of the subsidies as of 2009 (Szivós et al., 2011). DH users have also benefited from a preferential VAT rate of 5 per cent (instead of the 27 per cent standard rate) since 2010, resulting in the annual heating costs of an average 50 square-metre apartment served by DH being similar to those of an equallysized residential unit reliant on natural gas (Energia Klub, 2010). In is worth noting that the gázártámogatás and távhötámogatás schemes were merged with the household maintenance support programme (lakásfenntartási támogatás) in 2011, so as to encompass a wide range of household utility costs and allow for in-kind benefits such as the direct provision of fuel to households (Tirado Herrero, 2013).

Recent years have seen the emergence of a second wave of policy regulation. Allegedly motivated by the uninterrupted increase of household energy prices and energy burdens, the Hungarian government launched a series of decreed reductions in utility costs in December 2011. These measures - which are ongoing - declaratively aim to achieve, inter alia, 20 to 30 per cent reductions in the prices of natural gas, electricity and district heating by the end of 2014. They were accompanied by the restructuring of the energy regulator (the former Hungarian Energy Office), which was given a wider range of powers, as well as the establishment of legislative barriers towards the transfer of cost burdens to final energy users by energy companies (Pásztor, 2014). The measures have affected both the prices of energy carriers and the overall CPI (see Figures 1 and 2). Further steps in the same direction include recent proposals to scrap base fees in utility bills (BBJ, 2014a), intended price cuts for firewood and coal (BBJ, 2013), the investigation of 'money siphoning' (i.e. the payment of dividends to shareholders) by utility companies (BBJ, 2014b), the legal embedding of utility price cuts in the Constitution, and government plans to buy back, re-nationalize and turn energy companies into non-profit entities (Feher, 2013). This series of decisions can be seen as a reversal of the mid-2000s de-regulation of the energy sector - in line with more general reform trajectories in ECE - and is related to broader anti-EU developments in Hungary's energy policy, such as agreement to construct a new reactor in the Paks nuclear power together with the Russian Federation.

Just as previous government-led interventions, post-2012 utility cuts are firmly entangled in political strategies to gain electoral support by confronting EU institutions and international corporations. Presented as the 'battle of the utility bills' (rezsiharc), such efforts were a central theme of the right wing government's campaign before the April 2014 general elections, in which the populist Fidész party achieved a new parliamentary majority. While it is likely that the measures have brought short-term benefits to low-income households by allowing for a reduction in energy burdens, their ability to address the wider spatial and infrastructural components of energy vulnerability is questionable. This is because they have preferentially supported urban consumers of natural gas and district heating, while failing to provide relief to households (mostly in rural areas) relying on bottled natural gas or firewood as a source of heat (Szivós et al., 2011). Also, there are fears that the 
subsidies may increase rates of energy vulnerability by diverting resources that could be used for reducing the country's supply dependency on Russia, or investing in residential energy efficiency. Furthermore, it remains unclear whether or how utility companies will resist the price cuts by cutting investments in supply infrastructure or via litigation in international courts towards the compensation of incurred losses (Labelle, 2013).

\section{Conclusion: implications for research and policy}

This paper has sought to contribute to on-going debates about the definitions, driving forces and extent of domestic energy deprivation across developed and developing countries. We have argued that the inability to secure adequate energy services lies at the heart of this condition, as opposed to the focus on fuel, energy efficiency, and affordability that dominates most scientific and policy debates. While thinking in terms of energy services allows for all of these factors to be included into a single framework, it also emphasizes that deprivation in the home is deeply embedded in 'not only the resources (energies) necessary for its upkeep, but also the appliances, infrastructures, social norms and human action' (Bates et al., 2012 p. 108) within which the residential environment of the home is 'bound and reproduced'. At the same time, this approach has helped us identify the pathways through which households become unable to attain socio-materially sufficient levels of domestic energy functioning, while highlighting the importance of considering more complex and nuanced questions of need and vulnerability in the understanding of such processes.

The paper has also focused on the manner in which the propensity to experience a lack of adequate energy services has become a pervasive feature of both general consumption trends and the supply mix in Hungary. Thus, energy vulnerability approaches have allowed us to draw attention to some of the ways in which domestic energy deprivation is embedded in wider spatial and institutional landscapes, while operating at a variety of scales and material sites. But energy vulnerability does not necessarily suggest a passive set of behaviours and practices within households and institutions. Rather, it captures the systemic conditions that underpin the emergence of energy poverty, and the diverse strategies that are articulated with respect to the risk that this condition may be aggravated in the future. Contrary to arguments in the literature (Evans and Reid, 2014; Welsh, 2014) vulnerability in this context has spatial agency and helps articulate political work, as it forces state and private sector actors to adjust their policies in different ways, while serving as a basis for an entire host of household practices that challenge hegemonic orders.

The arguments presented here hint at the theoretical obsolescence of the notion of 'fuel poverty', even if the notion is widely recognized in policy and scientific circles. In purely discursive terms, fuel poverty incorrectly places an emphasis on the supply of energy carriers to the home, even if conceptual debates on the subject have significantly advanced past such understandings. We would also argue in favour of the need for considering energy service poverty as a truly global problem, which is just as much a question of ensuring an adequate match between energy resources, technical infrastructures and household needs, as it is about access, incomes and energy efficiency. This needs to transpire alongside the continued need for contextspecific research and advocacy on questions of energy access and deprivation, 
underlining the specific political circumstances that underpin the sheer absence of adequate infrastructures in some cases, and their inefficient operation in others. The conceptual commonalities highlighted in the paper are not aimed at reincarnating the much criticized 'one size fits all' approaches previously promoted by some international donors and multilateral organizations; rather we have sought to underline the binding together of services, needs and practices in the global rise of domestic energy deprivation.

At the same time, the paper has emphasized the need for integrating temporal dynamics and social resilience with understandings of energy services. Of particular importance in this context is the framework of 'energy vulnerability', which provides an encapsulation of the fluid nature of energy deprivation in the home, and the risk factors that contribute to the precariousness of particular spaces and groups of people. Energy vulnerability thinking can help challenge the predominantly sociodemographic approaches that pervades much of the literature and policy on 'vulnerable consumers' in the UK and the EU (for an example, see European Commission, 2013). This is because defining vulnerability in terms of purely social categories such as 'households on very low incomes, including pensioners, female single parent, and benefit recipients' (Jamasb and Meier, 2011 p. 0) neglects the role of housing and socio-technical factors in conditioning the propensity of a household to become unable of meeting its energy needs, while extending the debate to groups who may not necessarily face precarious household energy circumstances.

Policy-wise, moving the focus of state programmes towards energy services can lead towards the implementation of strategic measures aimed at ensuring that the needs and functionings of vulnerable household are satisfied, thus supplementing existing efforts to supply raw fuels to particular groups and places (Sovacool, 2011b). A widening of energy poverty amelioration frameworks towards the notion of 'services' also brings to the attention issues of public engagement, democracy and politics (Castán Broto, 2013), allowing affected groups to have a voice over the kinds of services and forms of utility provision that they need. Overall, it emphasizes the importance of access, reliability and built environment efficiency, by helping devise policies that address energy as a broader issue of human security in infrastructural terms. This, in turn, can help generate a wider awareness of energy poverty as a planetary scale problem, rather than a predicament specific to particular geographic settings.

\section{Acknowledgments}

The research leading to this paper has received funding from the European Research Council under the European Union's Seventh Framework Programme (FP7/20072013)/ERC grant agreement number 313478. The authors also wish to thank the two anonymous reviewers from the SPRU Working Paper series (SWPS) for their comments on an earlier draft.

\section{References}

Adkins, E., Eapen, S., Kaluwile, F., Nair, G., and Modi, V. (2010). 'Off-grid energy services for the poor: Introducing LED lighting in the Millennium Villages Project in Malawi'. Energy Policy 38: 1087-1097. 
Aune, M. (2007). 'Energy comes home'. Energy Policy 35: 5457-5465.

Baker, W., Starling, G., and Gordon, D. (2003). Predicting Fuel Poverty at the Local Level: Final Report on the Development of the Fuel Poverty Indicator. Bristol: Centre for Sustainable Energy.

Barnes, D. F. (2007). 'The challenge of rural electrification'. In D. F. Barnes (ed), The Challenge of Rural Electrification: Strategies for Developing Countries (pp. 1-17). Washington, D.C.: RFF Press.

Bates, O., Clear, A. K., Friday, A., Hazas, M., and Morley, J. (2012). 'Accounting for energy-reliant services within everyday life at home'. Pervasive Computing (pp. 107-124). Berlin and Heidelberg: Springer. Retrieved June 1, 2014, from http://link.springer.com/chapter/10.1007/978-3-642-31205-2_8

Bazilian, M., Nussbaumer, P., Eibs-Singer, C., Brew-Hammond, A., Modi, V., Sovacool, B., Ramana, V., et al. (2012). 'Improving Access to Modern Energy Services: Insights from Case Studies'. The Electricity Journal 25: 93-114.

Bazilian, M., Sagar, A., Detchon, R., and Yumkella, K. (2010). 'More heat and light'. Energy Policy, The socio-economic transition towards a hydrogen economy findings from European research, with regular papers 38: 5409-5412.

BBJ. (2013, September 16). 'Orbán prepares for "battle” over utility price cuts'. Budapest Business Journal. Retrieved from http://www.bbj.hu/politics/orbanprepares-for-battle-over-utility-price-cuts_69150

BBJ. (2014a, February 25). 'Fidesz proposal: Reduce or scrap utility bill base fees'. Budapest Business Journal. Retrieved from http://www.bbj.hu/politics/fideszproposal-reduce-or-scrap-utility-bill-base-fees_76277

BBJ. (2014b, February 19). 'Government investigating "money siphoning” of utility companies'. Budapest Business Journal. Retrieved from http://www.bbj.hu/politics/government-investigating-money-siphoning-ofutility-companies_76043

Bennett, J. (2005). 'The agency of assemblages and the North American blackout'. Public Culture 17: 445.

Bhattacharyya, S. C. (2006). 'Energy access problem of the poor in India: Is rural electrification a remedy?'. Energy Policy 34: 3387-3397.

Bhattacharyya, S. C. (2011). 'Energy Access'. Energy Economics (pp. 503-523). Springer London. Retrieved June 5, 2014, from http://link.springer.com/chapter/10.1007/978-0-85729-268-1_22

Bhide, A., and Monroy, C. R. (2011). 'Energy poverty: A special focus on energy poverty in India and renewable energy technologies'. Renewable and Sustainable Energy Reviews 15: 1057-1066.

Bilbao, S. N., and Castro, M. A. (2013). 'Pobreza energética. Cruz Roja ayuda a combatir la pobreza energética en España'. Energía de hoy.com 80-83.

Billen, G. (2008). 'Energie-Sozialtarife: Antwort auf drohende Energiearmut?'. Wirtschaftsdienst 88: 489-490.

Boardman, B. (1991). Fuel Poverty: From Cold Homes to Affordable Warmth. London: Bellhaven.

Boardman, B. (2010). Fixing Fuel Poverty: Challenges and Solutions. London: Earthscan.

Bouzarovski, S. (2013). 'Energy poverty in the European Union: landscapes of vulnerability'. Wiley Interdisciplinary Reviews: Energy and Environment http://onlinelibrary.wiley.com/doi/10.1002/wene.89/abstract. 
Bouzarovski, S., Gentile, M., and Salukvadze, J. (2010). 'A socially resilient urban transition? The contested landscapes of apartment building extensions in two post-communist cities'. Urban Studies 48: 2689-2714.

Bouzarovski, S., Petrova, S., Kitching, M., and Baldwick, J. (2013). 'Precarious domesticities: Energy vulnerability among urban young adults'. Energy Justice in a Changing Climate: Social Equity and Low-Carbon Energy (pp. 30-45). London: Zed Books.

Bouzarovski, S., Petrova, S., and Sarlamanov, R. (2012a). 'Energy poverty policies in the EU: A critical perspective'. Special Section: Fuel Poverty Comes of Age: Commemorating 21 Years of Research and Policy 49: 76-82.

Bouzarovski, S., Petrova, S., and Sarlamanov, R. (2012b). 'Energy poverty policies in the EU: A critical perspective'. Energy Policy 49: 76-82.

Bradshaw, M. (2010). 'Global energy dilemmas: a geographical perspective'. The Geographical Journal 176: 275-290.

Braubach, M., and Ferrand, A. (2013). 'Energy efficiency, housing, equity and health'. International Journal of Public Health 58: 331-332.

Brew-Hammond, A. (2010). 'Energy access in Africa: Challenges ahead'. Energy Policy, Greater China Energy: Special Section with regular papers 38: 22912301.

Bridge, G., Bouzarovski, S., Bradshaw, M., and Eyre, N. (2013). 'Geographies of energy transition: Space, place and the low-carbon economy'. Energy Policy 53: $331-340$.

Bruce, N. (2001). 'Household energy, health and development'. Journal of Epidemiology and Community Health 55: 221-222.

Brunner, K.-M., Spitzer, M., and Christanell, A. (2012). 'Experiencing fuel poverty. Coping strategies of low-income households in Vienna/Austria'. Energy Policy 49: 53-59.

Büchs, M., Bardsley, N., and Duwe, S. (2011). 'Who bears the brunt? Distributional effects of climate change mitigation policies'. Critical Social Policy 31: 285307.

Buzar, S. (2005). 'The institutional trap in the Czech rental sector: nested circuits of power, space and inequality'. Economic Geography 82: 381-405.

Buzar, S. (2007a). Energy Poverty in Eastern Europe: Hidden Geographies of Deprivation. Aldershot: Ashgate.

Buzar, S. (2007b). 'The "hidden" geographies of energy poverty in post-socialism: between institutions and households'. Geoforum 38: 224-240.

Buzar, S. (2007c). 'When homes become prisons: the relational spaces of postsocialist energy poverty'. Environment and Planning A 39: 1908-1925.

Buzar, S. (2007d). 'The "hidden" geographies of energy poverty in post-socialism: Between institutions and households'. Geoforum 38: 224-240.

Campbell, B. M., Vermeulen, S. J., Mangono, J. J., and Mabugu, R. (2003). 'The energy transition in action: urban domestic fuel choices in a changing Zimbabwe'. Energy Policy 31: 553-562.

Campbell, R. (1993). 'Fuel poverty and government response'. Social Policy \& Administration 27: 58-70.

Castán Broto, V. (2013). 'Symbolic Violence and the Politics of Environmental Pollution Science: The Case of Coal Ash Pollution in Bosnia and Herzegovina'. Antipode 45: 621-640.

Castán Broto, V., Allen, A., and Rapoport, E. (2012). 'Interdisciplinary Perspectives on Urban Metabolism'. Journal of Industrial Ecology 16: 851-861. 
Chapman, J. D. (1989). Geography and Energy: Commercial Energy Systems and National Policy. Harlow: Longman.

Chester, L. (2013). 'The Failure of Market Fundamentalism How Electricity Sector Restructuring is Threatening the Economic and Social Fabric'. Review of Radical Political Economics 45: 315-322.

Chester, L., and Morris, A. (2011). 'A New Form of Energy Poverty Is the Hallmark of Liberalised Electricity Sectors'. Australian Journal of Social Issues 46: 435.

Clancy, J., Ummar, F., Shakya, I., and Kelkar, G. (2007). 'Appropriate genderanalysis tools for unpacking the gender-energy-poverty nexus'. Gender \& Development 15: 241-257.

Cook, P. (2011). 'Infrastructure, rural electrification and development'. Energy for Sustainable Development, Special issue on off-grid electrification in developing countries 15: 304-313.

Crosbie, T., and Guy, S. (2008). 'En'lightening' energy use: the co-evolution of household lighting practices'. International Journal of Environmental Technology and Management 9: 220-235.

Cupples, J., Guyatt, V., and Pearce, J. (2007). '"Put on a jacket, you wuss": cultural identities, home heating, and air pollution in Christchurch, New Zealand'. Environment and Planning A 39: 2883 - 2898.

Dagoumas, A., and Kitsios, F. (2014). 'Assessing the impact of the economic crisis on energy poverty in Greece'. Sustainable Cities and Society. Retrieved April 22, 2014, from http://www.sciencedirect.com/science/article/pii/S2210670714000201

Department for International Development (DFID). (2002). Energy for the Poor: Underpinning the Millennium Development Goals. London: DFID.

Derdevet, M. (2013). 'La précarité énergétique, un chantier européen prioritaire'. Géoéconomie n ${ }^{\circ}$ 66: 37-50.

Devalière, I. (2013). 'L'inconfort thermique au cœur des inégalités entre les ménages. Appui sur l'Enquête Nationale Logement 2006'. Flux N 89-90: 58-66.

Dube, I. (2003). 'Impact of energy subsidies on energy consumption and supply in Zimbabwe. Do the urban poor really benefit?'. Energy Policy 31: 1635-1645.

Dubois, U. (2012). 'From targeting to implementation: The role of identification of fuel poor households'. Energy Policy 49: 107-115.

EC. (2011). A Roadmap for moving to a competitive low carbon economy in 2050 (Communication from the Commission to the European Parliament, the Council, the European Economic and Social Committee and the Committee of the Regions No. COM(2011) 112 final). Brussels: European Commission.

Eckholm, E. (1975). The other energy crisis: Firewood. Washington, D.C.: Worldwatch Institute.

Elias, R. J., and Victor, D. G. (2005). 'Energy transitions in developing countries: a review of concepts and literature'. Program on Energy and Sustainable Development, working paper. Stanford University: Stanford. Retrieved December 2, 2014, from http://www.trunity.net/files/158401_158500/158492/elias-and-victor-2005.pdf

Van Els, R. H., de Souza Vianna, J. N., and Brasil Jr., A. C. P. (2012). 'The Brazilian experience of rural electrification in the Amazon with decentralized generation - The need to change the paradigm from electrification to development'. Renewable and Sustainable Energy Reviews 16: 1450-1461. 
Energia Klub. (2010). 'Távhő körkép és kisokos 2 [District heating at a glance 2]'. Energia Klub / Energy Club. Retrieved from http://energiaklub.hu/hir/tavhokorkep-es-kisokos-2 $\backslash$

Energia Klub. (2011). 'Negajoules project. Results.'. Retrieved May 19, 2014, from http://www.negajoule.hu/oldal/adatok

E. On. Földgaz. (2008). 'The new Gas Act. A straight path into the future?'. Földgaz Magazin 2008/3.

European Commission. (2013). Vulnerable Consumer Working Group Guidance Document on Vulnerable Consumers, November 2013. Brussels: European Commission, Vulnerable Consumer Working Group.

Fahmy, E., Gordon, D., and Patsios, D. (2011). 'Predicting fuel poverty at a small-area level in England'. Energy Policy 39: 4370-4377.

Fankhauser, S., and Tepic, S. (2005). Can Poor Consumers Pay for Energy and Water?. Working Paper No. 92. London: European Bank for Reconstruction and Development.

Fankhauser, S., and Tepic, S. (2007). 'Can poor consumers pay for energy and water? An affordability analysis for transition countries'. Energy Policy 35: 10381049.

Feher, M. (2013, September 30). 'Hungary Mulls Cementing Utility Price Cuts in Constitution'. Emerging Europe. The Wall Street Journal, . Retrieved from http://blogs.wsj.com/emergingeurope/2013/09/30/hungary-mulls-cementingutility-price-cuts-in-constitution/

Fine, B. (1993). 'Modernity, urbanism, and modern consumption: a comment'. Environment and Planning D: Society and Space 11: $599-601$.

Fine, B., and Leopold, E. (1993). The world of consumption. London: Routledge. Retrieved December 3, 2014, from http://library.wur.nl/WebQuery/clc/924873

Foley, G. (1992). 'Rural electrification in the developing world'. Energy Policy, Energy and the Third World 20: 145-152.

Foster, J. E. (1998). 'Absolute versus relative poverty'. American Economic Review 88: $335-341$.

Fouquet, R. (2010). 'The slow search for solutions: Lessons from historical energy transitions by sector and service'. Energy Policy, Energy Efficiency Policies and Strategies with regular papers. 38: 6586-6596.

Freund, C. L., and Wallich, C. I. (1996). 'The welfare effects of raising household energy prices in Poland'. The Energy Journal 17: 53-77.

Goldthau, A., and Sovacool, B. K. (2012). 'The uniqueness of the energy security, justice, and governance problem'. Energy Policy 41: 232-240.

Green, J. M., and Erskine, S. H. (1999). 'Solar (photovoltaic) systems, energy use and business activities in Maphephethe, KwaZulu Natal'. Development Southern Africa 16: 221-237.

Gunningham, N. (2013). 'Managing the energy trilemma: The case of Indonesia'. Energy Policy, Decades of Diesel 54: 184-193.

Haanyika, C. M. (2008). 'Rural electrification in Zambia: A policy and institutional analysis'. Energy Policy 36: 1044-1058.

Haas, R., Nakicenovic, N., Ajanovic, A., Faber, T., Kranzl, L., Müller, A., and Resch, G. (2008). 'Towards sustainability of energy systems: A primer on how to apply the concept of energy services to identify necessary trends and policies'. Energy Policy, Transition towards Sustainable Energy Systems 36: 40124021. 
Hall, S. M., Hards, S., and Bulkeley, H. (2013). 'New approaches to energy: equity, justice and vulnerability. Introduction to the special issue'. Local Environment 18: 413-421.

Harrison, C., and Popke, J. (2011). '"Because you got to have heat": The networked assemblage of energy poverty in Eastern North Carolina'. Annals of the Association of American Geographers 101: 1-13.

Healy, J. D. (2004). Housing, Fuel Poverty and Health: a Pan-European Analysis. Aldershot: Ashgate.

Healy, J. D., and Clinch, J. P. (2004). 'Quantifying the severity of fuel poverty, its relationship with poor housing and reasons for non-investment in energysaving measures in Ireland'. Energy Policy 32: 207-220.

Heindl, P. (2013). Measuring Fuel Poverty: General Considerations and Application to German Household Data. Mannheim: ZEW Discussion Paper No. 13-046.

Hiemstra-van der Horst, G., and Hovorka, A. J. (2008). 'Reassessing the "energy ladder": Household energy use in Maun, Botswana'. Energy Policy 36: 33333344.

Hills, J. (2012). Getting the Measure of Fuel Poverty: Final Report of the Fuel Poverty Review. London: Centre for Analysis of Social Exclusion, London School of Economics and Political Science.

Hiteva, R. P. (2013). 'Fuel poverty and vulnerability in the EU low-carbon transition: the case of renewable electricity'. Local Environment 18: 487-505.

Howden-Chapman, P., Viggers, H., Chapman, R., O’Sullivan, K., Telfar Barnard, L., and Lloyd, B. (2012). 'Tackling cold housing and fuel poverty in New Zealand: A review of policies, research, and health impacts'. Energy Policy 134-142.

Ilskog, E., Kjellström, B., Gullberg, M., Katyega, M., and Chambala, W. (2005). 'Electrification co-operatives bring new light to rural Tanzania'. Energy Policy 33: 1299-1307.

Jalas, M., and Rinkinen, J. (2013). 'Stacking wood and staying warm: Time, temporality and housework around domestic heating systems'. Journal of Consumer Culture 1469540513509639.

Jamasb, T., and Meier, H. (2011). Energy Spending and Vulnerable Households (Working Paper). Cambridge: Faculty of Economics. Retrieved May 29, 2014, from http://www.repository.cam.ac.uk/handle/1810/241867

Jansen, J. C., and Seebregts, A. J. (2010). 'Long-term energy services security: What is it and how can it be measured and valued?'. Energy Policy, Energy Security - Concepts and Indicators with regular papers 38: 1654-1664.

Jansz, A., and Guertler, P. (2012). The Impact on the Fuel Poor of the Reduction in Fuel Poverty Budgets in England. London: Association for the Conservation of Energy.

Jencks, C., and Peterson, P. E. (Eds.). (2001). The Urban Underclass. Washington, D.C.: Brookings Institution Press.

Karekezi, S., and Kimani, J. (2002). 'Status of power sector reform in Africa: impact on the poor'. Energy Policy, Africa: Improving Energy Services for the Poor 30: 923-945.

Karjalainen, S. (2007). 'Gender differences in thermal comfort and use of thermostats in everyday thermal environments'. Building and Environment 42: 1594-1603.

Katsoulakos, N. (2011). 'Combating Energy Poverty in Mountainous Areas Through Energy-saving Interventions'. Mountain Research and Development 31: 284292. 
Kaygusuz, K. (2011). 'Energy services and energy poverty for sustainable rural development'. Renewable and Sustainable Energy Reviews 15: 936-947.

Kessides, I. (2000). Hungary: Regulatory and Structural Review of Selected Infrastructure Sectors. World Bank Technical paper no. 474. Europe and Central Asia Poverty Reduction and Economic Management Series. Washington, D.C: World Bank.

Kopatz, M. (2009). 'Energiearmut in Deutschland: Brauchen wir einen Sozialtarif?'. Energiewirtschaftliche Tagesfragen 59: 48-51.

Kovačević, A. (2004). Stuck in the Past: Energy, Environment and Poverty in Serbia and Montenegro. Belgrade: United Nations Development Programme.

KSH. (2014). '2.3.9. Piped gas supply (1990-)'. Központi Statisztikai Hivatal/Hungarian Central Statistical Office. Retrieved May 14, 2014, from http://www.ksh.hu/docs/eng/xstadat/xstadat_annual/i_zrk003.html

Labelle, M. (2013, September 21). 'Hungary morphes into a high risk environment for energy companies'. The Energy SCEE. Retrieved from http://energyscee.com/2013/03/21/hungary-evolution-to-a-high-riskenvironment-for-energy-companies/

Lawlor, D. A. (2001). 'The health consequences of fuel poverty: what should the role of primary care be?'. British Journal of General Practice 51: 435-436.

Lee, K. S., Anas, A., and Oh, G.-T. (1999). 'Costs of Infrastructure Deficiencies for Manufacturing in Nigerian, Indonesian and Thai Cities'. Urban Studies 36: 2135-2149.

Liddell, C. (2009). The Health Impacts of Fuel Poverty on Children. Save The Children. Belfast: University of Ulster.

Liddell, C. (2012). 'Fuel poverty comes of age: Commemorating 21 years of research and policy'. Energy Policy, Special Section: Fuel Poverty Comes of Age: Commemorating 21 Years of Research and Policy 49: 2-5.

Liddell, C., and Morris, C. (2010). 'Fuel poverty and human health: A review of recent evidence'. Energy Policy 2987-2997.

Li, K., Lloyd, B., Liang, X.-J., and Wei, Y.-M. (2014). 'Energy poor or fuel poor: What are the differences?'. Energy Policy 68: 476-481.

Lin, B., and Jiang, Z. (2011). 'Estimates of energy subsidies in China and impact of energy subsidy reform'. Energy Economics 33: 273-283.

Link, C. F., Axinn, W. G., and Ghimire, D. J. (2012). 'Household energy consumption: Community context and the fuelwood transition'. Social Science Research 41: 598-611.

Lutzenhiser, L. (1992). 'A cultural model of household energy consumption'. Energy 17: 47-60.

Mahama, A. (2012). '2012 international year for sustainable energy for all: African Frontrunnership in rural electrification'. Energy Policy, Special Section: Frontiers of Sustainability 48: 76-82.

Makdissi, P., and Wodon, Q. (2006). 'Fuel poverty and access to electricity: comparing households when they differ in needs'. Applied Economics 38: 1071-1078.

Masera, O. R., Saatkamp, B. D., and Kammen, D. M. (2000). 'From linear fuel switching to multiple cooking strategies: A critique and alternative to the energy ladder model'. World Development 28: 2083-2103.

McFarlane, C. (2011). 'The city as assemblage: dwelling and urban space'. Environment and Planning D: Society and Space 29: 649 - 671. 
Milne, G., and Boardman, B. (2000). 'Making cold homes warmer: The effect of energy efficiency improvements in low-income homes. A report to the Energy Action Grants Agency Charitable Trust'. Energy Policy 28: 411-424.

Miniaci, R., Scarpa, C., and Valbonesi, P. (2008). 'Distributional effects of price reforms in the Italian utility markets'. Fiscal Studies 29: 135-163.

Modi, V., McDade, S., Lallement, D., and Saghir, J. (2005). Energy services for the Millennium Development Goals. Washington D.C: The International Bank for Reconstruction and Development/The World Bank/ESMAP. Retrieved May 31, 2014, from http://www.cabdirect.org/abstracts/20083156488.html

Munasinghe, M. (1990). 'Rural electrification in the third world'. Power Engineering Journal 4: 189.

Murphy, J. T. (2001). 'Making the energy transition in rural east Africa: Is leapfrogging an alternative?'. Technological Forecasting and Social Change 68: 173-193.

Nansaior, A., Patanothai, A., Rambo, A. T., and Simaraks, S. (2011). 'Climbing the energy ladder or diversifying energy sources? The continuing importance of household use of biomass energy in urbanizing communities in Northeast Thailand'. Biomass and Bioenergy 35: 4180-4188.

Nussbaumer, P., Bazilian, M., and Modi, V. (2012). 'Measuring energy poverty: Focusing on what matters'. Renewable and Sustainable Energy Reviews 16: 231-243.

Nussbaum, M. C. (2011). Creating Capabilities. Cambridge, M.A.: Harvard University Press.

O'Brien, G., and Hope, A. (2010). 'Localism and energy: negotiating approaches to embedding resilience in energy systems'. Energy Policy 38: 7550-7558.

OECD/IEA. (2004). Coming in from the Cold. Improving District Heating Policy in Transition Economies. Paris, France: International Energy Agency.

OECD/IEA. (2007). Hungary 2006 review. Energy Policies of IEA Countries. Paris: International Energy Agency.

Osbaldeston, J. (1984). 'Fuel poverty in UK cities'. Cities 1: 366-373.

Ouedraogo, N. S. (2013). 'Energy consumption and human development: Evidence from a panel cointegration and error correction model'. Energy 63: 28-41.

Ozaki, R., and Shaw, I. (2014). 'Entangled Practices: Governance, Sustainable Technologies, and Energy Consumption'. Sociology 48: 590-605.

Pachauri, S. (2011). 'Reaching an international consensus on defining modern energy access'. Current Opinion in Environmental Sustainability, Energy Systems 3: 235-240.

Pachauri, S., and Jiang, L. (2008). 'The household energy transition in India and China'. Energy Policy, Transition towards Sustainable Energy Systems 36: 4022-4035.

Pachauri, S., Mueller, A., Kemmler, A., and Spreng, D. (2004). 'On Measuring Energy Poverty in Indian Households'. World Development 32: 2083-2104.

Pachauri, S., and Rao, N. D. (2013). 'Gender impacts and determinants of energy poverty: are we asking the right questions?'. Current Opinion in Environmental Sustainability, Energy systems 5: 205-215.

Pachauri, S., and Spreng, D. (2004). 'Energy use and energy access in relation to poverty'. Economic and Political Weekly 39: 271-278.

Pásztor, T. (2014, April 7). 'Public utility cost cuts continue, but criticism abounds'. International Law Office. Retrieved from 
http://www.internationallawoffice.com/newsletters/detail.aspx?g=a0251259f9de-4699-aba6-9f849d72e825

Paugam, S. (1995). 'The spiral of precariousness: a multidimensional approach to the process of social disqualification in France'. In G. Room (ed), Beyond the Threshold: The Measurement and Analysis of Social Exclusion (pp. 49-79). Bristol: The Policy Press.

Peng, W., Hisham, Z., and Pan, J. (2010). 'Household level fuel switching in rural Hubei'. Energy for Sustainable Development 14: 238-244.

Pereira, M. G., Freitas, M. A. V., and da Silva, N. F. (2010). 'Rural electrification and energy poverty: Empirical evidences from Brazil'. Renewable and Sustainable Energy Reviews 14: 1229-1240.

Petersen, L. K. (2008). 'Autonomy and Proximity in Household Heating Practices: the Case of Wood-Burning Stoves'. Journal of Environmental Policy \&amp; Planning 10: 423-438.

Petrova, S., Gentile, M., Mäkinen, I. H., and Bouzarovski, S. (2013). 'Perceptions of thermal comfort and housing quality: exploring the microgeographies of energy poverty in Stakhanov, Ukraine'. Environment and Planning A 45: $1240-1257$.

Poltimäe, H., and Võrk, A. (2009). 'Distributional Effects of Environmental Taxes in Estonia'. Discussions on Estonian economic policy: Theory and practice of economic policy. 17. Retrieved December 15, 2013, from http://ojs.utlib.ee/index.php/TPEP/article/view/915

Poputoaia, D., and Bouzarovski, S. (2010). 'Regulating district heating in Romania: Legislative challenges and energy efficiency barriers'. Large-scale wind power in electricity markets with Regular Papers 38: 3820-3829.

Reeve, I., Scott, J., Hine, D. W., and Bhullar, N. (2013). "'This is not a burning issue for me": How citizens justify their use of wood heaters in a city with a severe air pollution problem'. Energy Policy 57: 204-211.

Reister, D. B., and Devine Jr., W. D. (1981). 'Total costs of energy services'. Energy 6: 305-315.

Roberts, S. (2008a). 'Energy, equity and the future of the fuel poor'. Energy Policy 36: 4471-4474.

Roberts, S. (2008b). 'Demographics, energy and our homes'. Energy Policy, Foresight Sustainable Energy Management and the Built Environment Project 36: 46304632.

Robeyns, I. (2005). 'The Capability Approach: a theoretical survey'. Journal of Human Development 6: 93-117.

Rudge, J. (2012). 'Coal fires, fresh air and the hardy British: A historical view of domestic energy efficiency and thermal comfort in Britain'. Energy Policy 49: 6-11.

Ruggeri Laderchi, C., Olivier, A., and Trimble, C. (2013). Balancing Act: Cutting Energy Subsidies while Protecting Affordability. Washington, D. C: The World Bank. Retrieved April 22, 2014, from http://elibrary.worldbank.org/doi/book/10.1596/978-0-8213-9789-3

Sagar, A. D. (2005). 'Alleviating energy poverty for the world's poor'. Energy Policy 33: 1367-1372.

Saith, R. (2001). Capabilities: The Concept and Its Operationalisation. QEH Working Paper Series No. 66. Oxford: Queen Elizabeth House. 
Santamouris, M., Kapsis, K., Korres, D., Livada, I., Pavlou, C., and Assimakopoulos, M. N. (2007). 'On the relation between the energy and social characteristics of the residential sector'. Energy and Buildings 39: 893-905.

Santamouris, M., Paravantis, J. A., Founda, D., Kolokotsa, D., Michalakakou, P., Papadopoulos, A. M., Kontoulis, N., et al. (2013). 'Financial crisis and energy consumption: A household survey in Greece'. Energy and Buildings 65: 477487.

Sehjpal, R., Ramji, A., Soni, A., and Kumar, A. (2014). 'Going beyond incomes: Dimensions of cooking energy transitions in rural India'. Energy 68: 470-477.

Sen, A. (2009). The Idea of Justice. Cambridge: Belknap Press/Harvard University Press.

Seyfang, G., and Haxeltine, A. (2012). 'Growing grassroots innovations: exploring the role of community-based initiatives in governing sustainable energy transitions'. Environment and Planning-Part C 30: 381.

Shove, E. (2003). Comfort, cleanliness and convenience: The social organization of normality. Oxford: Berg. Retrieved June 9, 2014, from http://library.wur.nl/WebQuery/clc/1978670

Smil, V. (2003). Energy at the Crossroads: Global Perspectives and Uncertainties. Cambridge: MIT Press.

Southerton, D., Chappells, H., and Vliet, B. van (Eds.). (2004). Sustainable Consumption: The Implications of Changing Infrastructures of Provision. Edward Elgar Publishing.

Sovacool, B. K. (2011a). 'Conceptualizing urban household energy use: Climbing the "Energy Services Ladder". Energy Policy 39: 1659-1668.

Sovacool, B. K. (2011b). 'Security of energy services and uses within urban households'. Current Opinion in Environmental Sustainability, Energy Systems 3: 218-224.

Sovacool, B. K. (2012). 'The political economy of energy poverty: A review of key challenges'. Energy for Sustainable Development 16: 272-282.

Steel, K. (2007). 'Dynamics of Growth and Investment in the Kenyan Electric Power Sector'. IEEE Power Engineering Society General Meeting, 2007 (pp. 1-5). Presented at the IEEE Power Engineering Society General Meeting, 2007.

Stephenson, J., Barton, B., Carrington, G., Gnoth, D., Lawson, R., and Thorsnes, P. (2010). 'Energy cultures: A framework for understanding energy behaviours'. Energy Policy, The socio-economic transition towards a hydrogen economy findings from European research, with regular papers 38: 6120-6129.

Strengers, Y. (2012). 'Peak electricity demand and social practice theories: Reframing the role of change agents in the energy sector'. Energy Policy 44: 226-234.

Szivós, P., Bernát, A., and Kőszeghy, L. (2011). Managing household debt: Hungarian country report. Budapest, Hungary: Tárki Social Research Institute.

Terry, G. (2009). 'No climate justice without gender justice: an overview of the issues'. Gender \&amp; Development 17: 5-18.

Tews, K. (2014). 'Fuel Poverty in Germany: From a Buzzword to a Definition'. GAIA - Ecological Perspectives for Science and Society 23: 14-18.

Tirado Herrero, S. (2013). Fuel poverty alleviation as a co-benefit of climate investments: evidence from Hungary. Central European University, Budapest.

Tirado-Herrero, S., Jiménez-Meneses, L., López-Fernández, J. L., Martín-García, J., and Perero-Van-Hove, E. (2014). Pobreza energética en España. Análisis de tendencias. Asociación de Ciencias Ambientales. 
Tirado Herrero, S., López Fernández, J. L., and Martín García, P. (2012). Pobreza energética en España, Potencial de generación de empleo directo de la pobreza derivado de la rehabilitación energética de viviendas. Madrid, Spain: Asociación de Ciencias Ambientales.

Tirado Herrero, S., and Ürge-Vorsatz, D. (2012a). 'Trapped in the heat: A postcommunist type of fuel poverty'. Energy Policy 49: 60-68.

Tirado Herrero, S., and Ürge-Vorsatz, D. (2012b). 'Trapped in the heat: A postcommunist type of fuel poverty'. Special Section: Fuel Poverty Comes of Age: Commemorating 21 Years of Research and Policy 49: 60-68.

UNDP. (2004). Stuck in the Past.Energy, Environment and Poverty in Serbia and Montenegro. Belgrade, Serbia and Montenegro.: United Nations Development Programme.Country Office Serbia and Montenegro.

Ürge-Vorsatz, D., Miladinova, G., and Paizs, L. (2006). 'Energy in transition: From the iron curtain to the European Union'. Energy Policy 34: 2279-2297.

Valbonesi, P., Miniaci, R., and Scarpa, C. (2014). 'Fuel poverty and the energy benefits system: The Italian case'. $R \& R$ for Energy Policy. Retrieved April 22, 2014, from http://works.bepress.com/paola_valbonesi/30

Visagie, E. (2008). 'The supply of clean energy services to the urban and peri-urban poor in South Africa'. Energy for Sustainable Development 12: 14-21.

Walker, G. (2008). 'Decentralised systems and fuel poverty: Are there any links or risks?'. Energy Policy 36: 4514-4517.

Walker, G. (2014). 'The dynamics of energy demand: Change, rhythm and synchronicity'. Energy Research \& Social Science 1: 49-55.

Walker, G., and Day, R. (2012). 'Fuel poverty as injustice: Integrating distribution, recognition and procedure in the struggle for affordable warmth'. Energy Policy 49: 69-75.

Watson, J., Byrne, R., Morgan Jones, M., Tsang, F., Opazo, J., Fry, C., and CastleClarke, S. (2011). What are the major barriers to increased use of modern energy services among the world's poorest people and are interventions to overcome these effective? CEE Review 11-004. Collaboration for

Environmental Evidence: www.environmentalevidence.org/SR11004.html. Bangor: Collaboration for Environmental Evidence.

Welsh, M. (2014). 'Resilience and responsibility: governing uncertainty in a complex world'. The Geographical Journal 180: 15-26.

Wilhite, H., Shove, E., Lutzenhiser, L., and Kempton, W. (2000). 'The legacy of twenty years of energy demand management: we know more about individual behaviour but next to nothing about demand'. Society, behaviour, and climate change mitigation (pp. 109-126). Springer. Retrieved December 3, 2014, from http://link.springer.com/chapter/10.1007/0-306-48160-X_4

World Bank. (2014). 'Energy - the facts' http://web.worldbank.org/WBSITE/EXTERNAL/TOPICS/EXTENERGY2/0, contentMDK:22855502 pagePK:210058 piPK:210062 theSitePK:4114200,0 $0 . h$ tml.

Wrapson, W., and Devine-Wright, P. (2014). "'Domesticating" low carbon thermal technologies: Diversity, multiplicity and variability in older person, off grid households'. Energy Policy 67: 807-817.

Yohanis, Y. G. (2012). 'Domestic energy use and householders' energy behaviour'. Energy Policy, Modeling Transport (Energy) Demand and Policies 41: 654665. 
Zulu, L. C., and Richardson, R. B. (2013). 'Charcoal, livelihoods, and poverty reduction: Evidence from sub-Saharan Africa'. Energy for Sustainable Development, Special Issue on Charcoal 17: 127-137. 


\title{
Recent papers in the SPRU Working Paper Series:
}

SWPS 2014-13. Mariana Mazzucato, Carlota Perez. July 2014. “Innovation as Growth Policy: the challenge for Europe."

SWPS 2014-14. Daniele Rotolo, Loet Leydesdorff. July 2014. "Matching MEDLINE/PubMed Data with Web of Science (WoS): A Routine in $R$ language."

SWPS 2014-15. Patrick van Zwanenberg, Erik Millstone. August 2014. "Taste and power: The flavouring industry and flavour additive regulation."

SWPS 2014-16. Steve Sorrell. August 2014. "Energy Substitution, Technical Change and Rebound Effects."

SWPS 2014-17. Martin Binder, Alex Coad. September 2014. "How satisfied are the self-employed? A life domain view."

SWPS 2014-18. Davide Consoli, Francesco Vona, Francesco Rentocchini. September 2014. "That was then, this is now: Skills and Routinization in the 2000s."

SWPS 2014-19. Paul Nightingale, October 2014. "What is Technology? Six Definitions and Two Pathologies."

SWPS 2014-20. Matias Ramirez, Paloma Bernal, Ian Clarke, Ivan Hernandez. October 2014. "Distinguishing patterns of learning and inclusion through patterns of network formation in developing agricultural clusters."

SWPS 2014-21. Mariana Mazzucato, Caetano R. Penna. October 2014. "Beyond market failures. The market creating and shaping roles of state investment banks."

SWPS 2014-22. Steve Sorrell. October 2014. "Reducing energy demand: A review of issues, challenges and approaches."

SWPS 2014-23. Pablo D'Este, Alberto Marzucchi, Francesco Rentocchini. November 2014.

"Exploring and yet failing less: Learning from exploration, exploitation and human capital in R\&D."

SWPS 2014-24. Andy Stirling. November 2014. "Towards innovation democracy? Participation, responsibility and precaution in innovation governance."

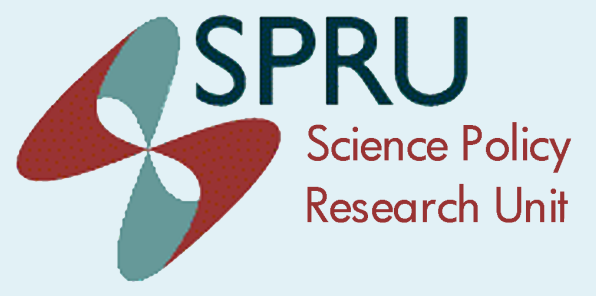

\author{
SPRU \\ Science Policy Research Unit \\ University of Sussex \\ Falmer, Brighton, BN1 9SL, UK \\ www.sussex.ac.uk/spru
}

